\title{
ALIRAN- ALIRAN DALAM TASAWUF
}

Leni Andariati

UIN Sunan Kalijaga Yogyakarta Email: leniandariati061996@gmail.com

\begin{tabular}{|l|l||l||l|}
\hline Received : & Submit : & Edited : & Published : \\
\hline 21 Juli 2020 & 21 Juli 2020 & 02 Agustus 2020 & 04 Agustus 2020 \\
\hline
\end{tabular}

\begin{abstract}
The journey of sufism its inception until today has experience various phases. This is indicated that sufism is not something obsolete, because it is able to adjust the development of this time without losing essential meaning. This article looks at the phases of defelopment in sufism from its inception to the present day, in addition it also dicusses the currents from sufism. This research was conducted with qualitative methods, the sources obtained from various of books, articles, and journals that accordance with the objek of research. This article found that sufism developed thrugh five phases, it is phases of formation, development, consolidation, philosophy, and purification phases. Each phases there is some character, so each character has a different style. The existence of these differences gave two streams in sufism, namely is semi-philosophy (falsafi) and Sunni sufism. Semi-philosopical sufism is characterized by syathahiyat, ehich a sufi experiences a spiritual drunkenness or ecstasy. And the sufis in sunni sufism are either conscious or not experiencing ecstasy.
\end{abstract}

Keywords: Sufism, Semi-Falsafi, Falsafi, Sunni

\begin{abstract}
ABSTRAK
Perjalanan tasawuf dari awal kemunculannya hingga hari ini telah mengalami berbagai fase. Hal ini menunjukkan bahwa tasawuf bukanlah sesuatu yang usang, karena ia mampu menyesuaikan diri dengan perkembangan zamannya tanpa menghilangkan makna esensialnya. Artikel ini melihat bagaimana fase-fase perkembangan dalam tasawuf tersebut dari awal kemunculannya hingga hari ini, selain itu juga membahas aliran-aliran yang ada di dalamnya. Penelitian ini dilakukan dengan metode kualitatif, di mana sumber-sumbernya diperoleh dari berbagai buku, artikle, dan jurnal yang sesuai dengan objek penelitian. Penelitian ini menemukan bahwa tasawuf berkembang melalui lima fase, yaitu fase pembentukan, pengembangan, konsolidasi, falsafi, dan fase pemurnian. Setiap fase memiliki tokohnya sendiri-sendiri, sehingga dari masingmasing tokoh mempunyai corak yang berbeda-beda. Adanya perbedaan tersebut melahirkan dua aliran dalam tasawuf, yaitu aliran tasawuf semi-falsafi yang menjadi tasawuf falsafi dan tasawuf sunni. Tasawuf semi-falsafi (falsafi) ditandai dengan syathahiyat, di mana seorang sufi mengalami kemabukan spiritual atau ekstase. Sedangkan sufi dalam tasawuf sunni berada dalam keadaan sadar atau tidak mengalami ekstase.
\end{abstract}

Kata Kunci: Tasawuf, Semi-Falsafi, Falsafi, Sunni 


\section{PENDAHULUAN}

Mengkaji tentang tasawuf bukanlah sesuatu yang mudah untuk dilakukan, dikarenakan cakupannya yang begitu luas dan mendalam, sehingga tidak cukup jika hanya mencakup aspek historis ataupun fenomenologis saja, melainkan juga meliputi aspek subjektivitas dari masing-masing sufi. Dalam perjalanannya tasawuf terus mengalami perkembangan dan mengalami beberapa fase, dimulai dari fase pembentukan, pengembangan, konsolidasi, falsafi, hingga fase pemurnian. Dari masing-masing fase tersebut, para sufi memiliki konsepsi, pemahaman, dan cara yang berbeda-beda antara satu fase dengan fase yang lain. Perbedaan tersebut terlihat dari adanya dua aliran dalam tasawuf, yaitu tasawuf semi-falsafi yang kemudian berubah menjadi tasawuf falsafi dan tasawuf sunni. Tasawuf semi-falsafi adalah tasawuf yang ajarannya disusun secara mendalam dengan menggunakan bahasa-bahasa simbolik-filosofis. Sehingga tidak mengeherankan jika kebanyakan sufi yang mengikuti aliran ini akan mengalami ekstasi (kemabukan spiritual) dan mengeluarkan statement yang terkesan ganjil (syathahiyat). Para sufi yang termasuk dalam aliran ini adalah Abu Yazid al-Bustami, Abu Mansur al-Hallaj, dan Ibn Arabi. Tasawuf semifalsafi sulit dipahami oleh orang-orang awam, bahkan ajarannya terkesan rumit untuk dipahami.

Tasawuf sunni merupakan tasawuf yang ajarannya didasarkan pada al-Qur'an dan Sunnah Nabi Muhammad Saw., selain itu calon sufi juga diharuskan untuk meningkatkan kualitas diri, memahami syari'at dengan sebaik-baiknya. Tasawuf sunni mendasarkan pengalaman kesufiannya dengan pemahaman yang sederhana dan mudah dipahami bagi orang awam. Tokoh yang memprakarsai adalah al-Junaid al-Baghdadi, al-Qusyairi, alHiwari, dan al-Ghazali.

\section{Masa Pembentukan Tasawuf}

Pada permulaan Islam (masa Nabi dan Khulafa ar-Rasyidin) istilah tasawuf belumlah dikenal. Namun praktek-praktek seperti puasa, zuhud, dan yang senada dengan itu telah ada. Hal tersebut dapat dibuktikan dari perilaku Abdullah ibn Umar yang sering melakukan puasa sepanjang hari dan shalat serta membaca al-Qur'an di malam harinya. Selain itu, sahabat lain yang juga terkenal adalah Abu al-Darda', Abu Dzar al-Ghiffari, Bahlul ibn Zubaid, dan Kahmas al-Hilali. ${ }^{1}$ Baru paruh kedua abad ke 1 Hijriyah, muncullah Hasan al-Basri yang

${ }^{1}$ M. Amin syukur, Menggugat Tasawuf: Sufisme dan Tanggung Jawab Sosial Abad 21, (Yogyakarta: Pustaka Pelajar, 2002), 30. 
merupakan seorang tokoh zahid pertama dan termasyhur dalam sejarah tasawuf. Hasan alBasri melahirkan beberapa ajaran yang kemudian dilanjutkan oleh orang-orang setelahnya sebagai sebuah pembaharuan hidup kerohanian di kalangan Islam. Ajaran-ajaran yang muncul pada abad ini meliputi khauf, raja', ju' (sedikit makan), sedikit bicara, sedikit tidur, zuhud, khalwat, memperbanyak shalat sunnah dan puasa, menahan nafsu, hidup sederhana, dan lain sebagainya. Para zahid di abad ini sangat kuat memegang dimensi eksternal Islam (Syari'ah) sekaligus dimensi internal (bathiniyyah). ${ }^{2}$

Selanjutnya untuk abad II Hijriah muncul zahid perempuan dari Basrah-Irak, yaitu Rabi'ah al-Adawiyah. Ia memunculkan ajaran cinta kepada Tuhan (Hubb Allah). Di abad ini tasawuf tidak banyak perbedaan dengan abad sebelumnya, masih bercorak kezuhudan. Meskipun demikian, di abad ini juga mulai bermunculan jalan-jalan untuk membersihkan jiwa, kemurnian hati, berdiam diri, melakukan safar, memperbanyak dzikir dan riyadlah. Tokoh yang memperkenalkan istilah tersebut adalah Ali Syaqiq al-Balkhy, Ma'ruf al-Karkhy, dan Ibrahim ibn Adam. ${ }^{3}$

\section{Masa Pengembangan Tasawuf}

Masa pengembangan tasawuf terjadi pada abad ke III dan ke IV H. Dalam abad ini mulai muncul dua aliran yang saling bertentangan dari kalangan sufi, yaitu tasawuf semifilosofis dan tasawuf sunni. Dua aliran besar tasawuf inilah yang pada gilirannya berkembang di seluruh dunia Islam. ${ }^{4}$

\section{Tasawuf Semi-Filosofis}

Para penganut aliran tasawuf semi-filosofis cenderung mengungkapkan ungkapanungkapan ganjil (syathahiyat) serta bertolak dari keadaan fana' menuju pernyataan tentang terjadinya penyatuan ataupun hulul. Tasawuf model ini identik dengan tasawuf tipe keadaan mabuk (sukr, intoxication), yang dikuasai oleh perasaan kehadiran Tuhan, di mana para sufi melihat Tuhan dalam segala sesuatu dan kehilangan kemampuan untuk membedakan antara makhluk-makhluk. Keadaan ini disertai oleh keintiman (uns), rasa kedekatan Tuhan yang mencintai. Menurut Kautsar, bahwasanya para sufi yang mabuk merasakan keintiman dengan Tuhan dan sangat yakin pada kasih sayang-Nya, mereka juga menyatakan dengan terangterangan persatuannya dengan Tuhan. Tokohnya yaitu Abu Yazid al-Busthami, Abu Mansur

${ }^{2}$ M. Amin syukur, Menggugat Tasawuf..., 31

${ }^{3}$ M. Amin syukur, Menggugat Tasawuf..., 31

${ }^{4}$ Abu al-Hasan Ali ibn Utsman Al-Hujwiri, Kasyf al-Mahjub: The Oldest Persian Treatise On Sufisme, (New Delhi: Taj Company, 1999), 186. 
al-Hallaj, Ibn Atha', al-Syibli, Bundar Ibn Husain, Abu Hamzah al-Baghdadi, Summun alMuhibb, dan beberapa sufi Irak. Dari mereka inilah kemudian dapat ditemukan bibit-bibit ajarannya pada diri Ibn Arabi dalam sistem ajaran wahdat al-wujud. ${ }^{5}$ Semua sufi tersebut mengakui bahwa semua itu tidak akan tercapai tanpa melakukan latihan yang teratur (riyadhah). ${ }^{6}$ Ajaran yang muncul di abad ini adalah paham fana', baqa', ittihad, dan hulul.

\section{Fana' dan Baqa'}

Paham fana' dan baqa' dicetuskan oleh Abu Yazid al-Bustami. Fana' secara bahasa berasal dari faniya yang berarti musnah atau lenyap. Sedangkan dalam istilah tasawuf, fana' adalah keadaan moral yang luhur. Sedangkan Abu Bakar al-Kalabadzi mendefinikan fana' sebagai hilangnya semua keinginan hawa nafsu seseorang, tiadanya pamrih dari segala perbuatan manusia, sehingga ia kehilangan segala perasaannya dan membedakan sesuatu secara sadar, dan ia telah menghilangkan semua kepentingan ketika berbuat sesuatu. Pencapaian Abu Yazid ke tahap fana' terjadi setelah meninggalkan segala keinginan selain keinginan kepada Allah. Dengan demikian jelaslah bahwa materi manusianya tetap ada dan sama sekali tidak hilang ataupun hancur, yang hilang hanyalah kesadaran akan dirinya sebagai manusia. Orang yang dalam keadaan fana' tidak lagi merasakan eksistensi jasad kasarnya. $^{7}$

Bagi Abu Yazid al-Bustami, manusia pada hakikatnya seesensi dengan Tuhannya, sehingga dapat bersatu dengan-Nya apabila ia dapat melebur eksistensi keberadaannya sebagai suatu pribadi hingga ia tidak menyadari pribadinya (fana an-nafs), yaitu hilangnya kesadaran akan jasad tubuh kasarnya, kesadarannya menyatu dengan dzat Allah. ${ }^{8}$ Adapun baqa' berasal dari kata baqiya yang berarti tetap, sedang dalam istilah tasawuf berarti mendirikan sifat-sifat terpuji kepada Allah. Paham baqa' ini tidak dapat dipisahkan dengan paham fana', keduanya merupakan pasangan. Jadi ketika seorang sufi sedang mengalami fana', maka ketika itu juga ia sedang mengalami baqa'. Dengan demikian dapat dipahami bahwa yang dimaksud dengan fana' adalah lenyapnya sifat-sifat basyariah, akhlak yang tercela, perbuatan maksiat dan kebodohan dalam diri manusia. Sedangkan baqa' merupakan kekalnya sifat ketuhanan, akhlak terpuji, dan kebersihan diri dari dosa dan maksiat. Untuk

\footnotetext{
${ }^{5}$ Al-Hujwiri, Kasyf al-Mahjub...., 180

${ }^{6}$ M. Amin syukur, Menggugat Tasawuf..., 36

${ }^{7}$ Zakiah Daradjat, Pengantar Ilmu Tasawuf, (Sumatera Utara: Institut Agama Islam Negeri, 1982), 159

${ }^{8}$ Zakiah Daradjat, Pengantar Ilmu Tasawuf...., 158
} 
dapat mencapai baqa' ini dibutuhkan usaha dari calon sufi, seperti bertaubat, berdzikir, beribadah, serta menghiasi diri dengan akhlak terpuji. ${ }^{9}$

\section{Ittihad}

Ittihad adalah tahapan lanjutan yang dialami seorang sufi setelah melalui tahapan fana' dan baqa'. Menurut Harun Nasution, ittihad adalah sebuah tingkatan dimana seorang sufi telah merasa dirinya bersatu dengan Tuhan, satu tingkatan antara yang mencintai dan yang dicintai telah menjadi satu, sehingga salah satu dari mereka dapat memanggil yang satu lagi dengan kata-kata "Hai Aku". Dalam ittihad, yang dilihat hanyalah satu wujud, sungguhpun sebenarnya ada dua wujud yang berpisah antara yang satu dengan yang lain. Karena yang dilihat dan dirasakan hanyalah satu wujud. Dalam ittihad bisa terjadi pertukaran antara yang mencintai dan yang dicintai, yaitu antara sufi dengan Tuhan. Dalam ittihad, identitas diri itu telah hilang, identitasnya telah menjadi satu. Sufi yang bersangkutan, karena kefana'annya ia tidak lagi mempunyai kesadaran dan akan berbicara atas nama Tuhan. ${ }^{10}$

Sejarah tasawuf menunjukkan bahwa Abu Yazid lah yang dianggap sebagai pembawa arah timbulnya aliran "kesatuan wujud”. Dengan fana'-nya Abu Yazid meninggalkan dirinya dan pergi ke hadirat Tuhan. Bukti bahwa ia telah berada di dekat Tuhan dapat dilihat dari syathahat yang diucapkannya. Menurut at-Taftazani, ungkapan Abu Yazid tentang fana' dan ittihad memang terlalu berlebih-lebihan. Seperti yang pernah dialami Abu Yazid ketika sehabis shalat subuh ia berucap:

Terjemahnya :

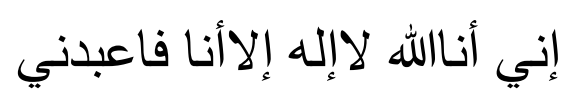

"Tidak ada Tuhan selain Aku maka sembahlah Aku". 11

Selain itu masih banyak ucapan-ucapannya yang bertendensi ke arah timbulnya paham ittihad. Dan hampir semua ucapan Abu Yazid tersebut terdengar secara sepintas memberikan kesan bahwa ia sudah syirik kepada Allah. Oleh karena itulah, banyak sufi yang ditangkap dan dipenjarakan bahkan dibunuh karena ucapannya yang membingungkan golongan masyarkat awam.

\section{Hulul}

Paham hulul sebagai salah satu aliran dalam tasawuf yang merupakan tipe lain dari paham ittihad yang diajarkan oleh Abu Yazid al-Bustami. Hulul pertama kali dicetuskan oleh Abu al-Mugis al-Husein bin Mansur bin Muhammad al-Baidawi, dan lebih dikenal dengan nama al-Hallaj. Lahir di Persia tahun $858 \mathrm{M}$, dan meninggal tahun $922 \mathrm{M}$ akibat dihukum

\footnotetext{
${ }^{9}$ Afif Anshori, Tasawuf Filsafat Syaikh Hamzah Fansuri, (Jakarta: Gelombang Pasang, 2004), 167

${ }^{10}$ Harun Nasution, Filsafat dan Mistisime dalam Islam, (Jakarta: Bulan Bintang, 1973), 79

${ }^{11}$ M. Sholihin dan Rosihon Anwar, Ilmu Tasawuf,(Bandung: Pustaka Setia, 2011), 164
} 
mati di Baghdad karena paham hulul yang diajarkannya. Hulul adalah Tuhan mengambil tempat dalam tubuh manusia, di mana manusia tersebut telah mampu melenyapkan sifat-sifat kemanusiaannya melalui fana'. Menurut al-Hallaj, manusia itu mempunyai sifat dasar yang ganda, yaitu sifat ketuhanan (lahut) dan sifat kemanusiaan (nasut). Demikian juga dengan Allah yang memiliki sifat dasar ketuhanan (lahut) dan juga terdapat sifat kemanusiaan (nasut). Apabila sifat-sifat kemanusiaan itu telah dilenyapkan melalui fana' dan sifat-sifat ketuhanan dikembangkan, maka akan tercapailah persatuan dengan Tuhan dalam bentuk hulul. $^{12}$

Manusia harus terlebih dahulu meninggalkan sifat-sifat kemanusiaannya agar bersatu dengan Tuhannya. Setelah sifat kemanusiaan hilang dan tinggal sifat ketuhanan yang ada dalam dirinya, disitulah Tuhan dapat mengambil tempat dalam dirinya, dan ketika itu roh Tuhan dan roh manusia bersatu dalam diri manusia. menurutnya, dalam hulul terkandung kefanaan total kehendak manusia dalam kehendak Ilahi, sehingga setiap kehendaknya itulah kehendak Tuhan, demikian juga dengan tindakannya. ${ }^{13}$ Menurut al-Hallaj, dengan cara seperti itu maka seorang sufi bisa bersatu dengan Tuhannya. Sehingga ketika al-Hallaj berkata "Ana al-Haqq" (Aku adalah Tuhan) bukanlah roh al-Hallaj yang mengucapkan kata itu, namun roh Tuhan yang mengambil tempat dalam dirinya. ${ }^{14}$ Meski demikian, al-Hallaj sebenarnya tidak mengakui bahwa dirinya Tuhan ataupun sama dengan Tuhan. Seperti penegasan yang ada dalam sya'irnya:

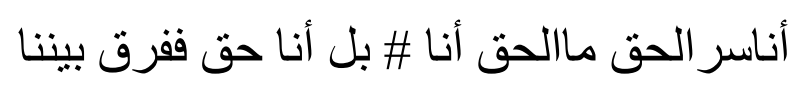

Terjemahannya:

"Aku adalah rahasia yang Maha Benar dan bukanlah yang Maha Benar itu Aku, aku hanya satu dari yang benar, maka bedakanlah antara kami”. ${ }^{15}$

Terlihat bahwa hulul yang terjadi pada al-Hallaj adalah sekedar kesadaran psikis yang berlangsung pada kondisi fana', yaitu ungkapan sekedar terlebarnya nasut dalam lahut, jadi antara keduanya tetap ada perbedaan.

\footnotetext{
${ }^{12}$ R.A. Nicholson, The Mystic of Islam, (London: Routledge and Kegan Paul Ltd, 1966), 150

${ }^{13}$ Al-Taftazani, Sufi dari Zaman ke Zaman..., 127

${ }^{14}$ Asmaran As, Pengantar Studi Tasawuf..., 311

${ }^{15}$ Harun Nasution, Filsafat dan Mistisime..., 90
} 


\section{Tasawuf Sunni}

Tasawuf sunni adalah tasawuf yang banyak dikembangkan oleh kaum salaf, dimana ajaran-ajarannya lebih mengarah pada perilaku yang sesuai dengan al-Qur'an dan Sunnah Nabi Muhammad Saw., jalan untuk meningkatkan kualitas diri kepada Allah, untuk melancarkan misi kaum salaf tersebut maka seorang calon sufi haruslah terlebih dahulu memahami syari'at dengan sebaik mungkin. Selain itu, tasawuf sunni mendasarkan pengalaman kesufiannya dengan pemahaman yang sederhana, sehingga dapat dipahami oleh manusia pada umumnya. Tasawuf sunni berbeda dengan tasawuf semi falsafi, jika para sufi tasawuf semi-falsafi mengalami syathahiyat, kemabukan spiritual ataupun ekstase, maka para sufi tasawuf sunni berada dalam keadaan sadar atau tidak mabuk. Keadaan sadar atau tidak mabuk (shahw, sobriety) dipenuhi dengan rasa takut dan hormat (haybah), rasa bahwa Tuhan betapa agung, perkasa, penuh murka, dan jauh, yang tidak peduli dengan persoalan-persoalan kecil umat manusia. ${ }^{16}$

Sufi dalam tasawuf sunni selalu dalam keadaan sadar sehingga terus dikuasai oleh rasa takut dan hormat kepada Tuhan serta tetap khawatir terhadap kemurkaan-Nya. Dari situlah mereka memelihara kesopanan $(a d a b)$ terhadap Tuhan. Tasawuf tipe ini tidak dapat dipisahkan dengan syari'at karena bagi para penganutnya, syari'at adalah jalan awal yang harus ditempuh untuk menuju tasawuf. ${ }^{17}$ Tasawuf sunni diprakarsai oleh Syaikh Junaid alBaghdadi. Beliau memagari tasawufnya dengan al-Qur'an dan al-Hadis serta mengaitkan keadaan dan tingkatan rohaniah mereka dengan keduanya. ${ }^{18}$ Ajarannya kemudian dikembangkan oleh al-Ghazali. ${ }^{19}$ Tujuan akhir dari tasawuf sunni adalah terbentuknya moral yang sempurna serta menuai Ma'rifat Allah. ${ }^{20}$

Tasawuf sunni banyak pengikutnya terutama di negara-negara yang bermazhab Syafi'i, hal ini dikarenakan penampilan paham dan ajaran-ajarannya yang tidak terlalu rumit. Adapun ciri-ciri dari tasawuf sunni yaitu:

1. Melandaskan diri pada al-Qur'an dan Sunnah,

2. Tidak menggunakan terminologi-terminologi filsafat, sebagaimana terdapat dalam ungkapan syathahiyat,

3. Lebih bersifat mengajarkan dualisme dalam hubungan antara Tuhan dan manusia,

\footnotetext{
${ }^{16}$ Kautsar Azhari Noer, Tasawuf Perenial Kearifan Kritis Kaum Sufi, (Jakarta: Serambi, 2002), 17

17 Ahmad Najib Burhani, Manusia Modern Mendamba Allah: Renungan Tasawuf Positif, (Jakarta: Mizan, 2002), 83

${ }^{18}$ J. Spencer Trimingham, The Sufi Orders in Islam, (London: Oxford University Press, 1971), 4

${ }^{19}$ Abu al-Hasan Ali ibn Utsman Al-Hujwiri, Kasyf al-Mahjub...., 185

${ }^{20}$ Aly Mashar, Tasawuf: Sejarah, Madzhab, dan Inti Ajarannya, Al-A'raf: Jurnal Pemikiran Islam dan Filsafat, Vol. XII, No. 1, Juni 2015, 14
} 
4. Kesinambungan antara haqiqat dan syari'ah,

5. Lebih berkonsentrasi pada soal pembinaan, pendidikan akhlak, serta pengobatan jiwa dengan cara riyadlah (latihan mental) dan langkah takhalli, tahalli, dan tajalli. ${ }^{21}$

\section{Junaid Al-Baghdadi}

Nama lengkapnya adalah Abu al-Qasim al-Junaid bin Muhammad al-Khazzaz alNihawandi. Dia meninggal di Bagdad pada tahun 297 H / 910 M. Dia merupakan salah seorang tokoh sufi yang sangat luar biasa, teguh dalam menjalankan syari'at agama dan sangat mendalam jiwa kesufiannya. Hingga ia mendapatkan julukan sebagai Imam Kaum Sufi (Syaikh al-Ta'ifah). ${ }^{22}$ Al-Junaid merupakan sufi yang bersifat moderat atas apa yang terjadi dengan Abu Yazid al-Bustami. Dia mewakili tasawuf para fuqaha yang mendasarkan diri pada al-Qur'an dan Sunnah secara riil. Tasawuf al-Junaid dapat diketahui dari ungkapannya bahwa "Barang siapa tidak menghafal al-Qur'an dan tidak menulis hadis, maka ia tidak boleh dijadikan panutan dalam permasalahan tasawuf. Karena ilmu itu terikat dengan al-Qur'an dan Sunnah." "Semua jalan tertutup bagi semua makhluk kecuali bagi orang-orang yang meneladani asar Nabi, mengikuti sunnahnya dan konsisten dengan jalannya, maka baginya semua jalan kebajikan akan terbuka.",23

Al-Junaid dikenal dalam sejarah tasawuf sebagai seorang sufi yang banyak membahas tentang tauhid. Tauhid yang dimaknakan oleh al-Junaid memiliki unsur utama berupa pemisahan yang baqa' dan yang fana'. Tauhid yang hakiki adalah buah dari fana' terhadap semua yang selain Allah. Akibat sirnanya perasaan dan gerakan dengan kepercayaan penuh bahwa Allah melakukan segala sesuatu bagi hambaNya. Pengertian tauhid seperti inilah yang merupakan kefanaan dari hal yang normal, baik dalam kehendak maupun pandangan. Hal ini kemudian banyak mendapat perhatian dari para sufi setelahnya. Dia juga menandaskan bahwa tasawuf berarti bahwa Allah akan menyebabkan kau mati dari dirimu sendiri dan hidup didalamNya. Peniadaan diri seperti inilah yang dimaksudkan al-Junaid sebagai fana', sebuah istilah yang mengingatkan kepada ungkapan Qur'ani "Segala sesuatu akan binasa kecuali wajah-Nya" (QS. 55: 26-27), dan hidup dalam Dia adalah baqa'.

Al-Junaid menganggap bahwa tasawuf merupakan penyucian dan perjuangan kejiwaan yang tiada habisnya, yaitu "manusia tidak akan melaksanakan tasawuf dengan obrolan dan kata-kata, tetapi dari kelaparan dan penolakan terhadap dunia dan pemutusan

\footnotetext{
${ }^{21}$ Samsul Munir Amir, Ilmu Tasawuf, (Jakarta: Amzah, 2012), 143

22 Asmaran As, Pengantar Studi Tasawuf, (Jakarta: RajaGrafindo Persada, 1994), 296

23 Abu al-Wafa al-Ghanimi at-Taftazani, Sufi dari Zaman ke Zaman, terj. Ahmad Rifa'i Ustmani, (Bandung: Pustaka, 1985), 114
} 
hubungan dengan hal-hal yang sudah menjadi kebiasaannya." Bagi al-Junaidi, kehidupan tasawuf berarti usaha abadi manusia untuk kembali ke asal-usulnya, yang bersumber pada Allah awal mula segala sesuatu, sehingga akhirnya dia bisa mencapai suatu keadaan "dimana dia berada sebelum berada”. Hanya dalam keadaan seperti itulah orang bisa meyadari tauhid sempurna, hanya pada saat itulah ia bersaksi bahwa Tuhan adalah Esa dari keabadian ke keabadian. ${ }^{24}$ Dalam kenyataannya, al-Junaid adalah tokoh yang penting dalam sejarah tasawuf. Hal ini terlihat dari pandangan-pandangannya yang kaya, sikapnya yang selalu memadukan syari'at dengan hakikat, selain itu dia juga merupakan sufi yang tidak suka mengeluarkan ungkapan-ungkapan yang ganjil. ${ }^{25}$ Dia lebih mendahulukan kesadaran ketimbang ketidaksadaran (trance). Dan lebih mendahulukan kebaqa'an ketimbang kefana'an. $^{26}$

\section{Masa Konsolidasi Tasawuf}

Masa yang berjalan pada kurun abad ke $\mathrm{V} \mathrm{H}$, ditandai dengan tumbuh dan semakin berkembanganya tasawuf sunni, di mana hal tersebut berbanding terbalik dengan tasawuf semi-falsafi yang mulai tenggelam dan baru muncul kembali abad ke VI Hijriah dan seterusnya dengan bentuk yang lain. Tenggelamnya tasawuf semi-falsafi pada abad ke V Hijriah dikarenakan oleh berjayanya aliran teologi Ahlus Sunnah wal Jama'ah yang dibawakan oleh Abu al-Hasan al-Asy'ari atas aliran-aliran Abu Yazid al-Bustami dan alHallaj ataupun para sufi yang lain yang ungkapannya terkenal ganjil (syathahiyat), mereka pun dianggap melenceng dari kaidah dan akidah Islam. Karena hal inilah, tasawuf di abad ke V Hijriah lebih fokus untuk melakukan pembaharuan, yaitu dengan mengembalikan segala sesuatunya pada al-Qur'an dan as-Sunnah. Sufi yang paling utama dan menonjol di abad ini adalah al-Ghazali. ${ }^{27}$ Pemikiran al-Ghazali dipengaruhi oleh dua tokoh sebelumnya, yaitu alQusyairi dan al-Harawi.

\section{Al-Ghazali}

Al-Ghazali merupakan tokoh pembela sunni terbesar, bahkan lebih besar dibanding dengan Abu Hasan al-Asy'ari. Nama lengkapnya adalah Abu Hamid Muhammad bin Muhammad bin Muhammad bin Muhammad bin Ahmad al-Tusi al-Syafi'i, dan lebih dikenal

\footnotetext{
${ }^{24}$ Asmaran As, Pengantar Studi Tasawuf..., 302

${ }^{25}$ Al-Sarraj al-Tusiy, al-Luma' fi Tarikh al-Tasawwuf al-Islamiy, (Beirut: Dar al-Kutub al-Ilmiyyah, 2007), 47

${ }^{26}$ Renold Alan Nocholson, Fi al-Tasawwuf al-Islami wa Tarikhihi, (Kairo: Dar al-Ta'lif, 1969), 112

${ }^{27}$ A.J.Arberry, Sufism: An Account of The Mystics of Islam, (London: George Allen \& Unwin, 1979), 94
} 
dengan nama al-Ghazali. Dilahirkan di suatu tempat yang bernama Gazalah, di daerah Tus yang terletak di wilayah Khurasan pada tahun $450 \mathrm{H} / 1058 \mathrm{M}^{28}$ Sebagaimana para sufi sebelumnya yang memandang bahwa ma'rifat adalah tujuan akhir yang harus dicapai manusia, yang sekaligus merupakan kesempurnaan tertinggi yang didalamnya terkandung kebahagiaan yang hakiki. Ma'rifat dari segi bahasa berarti ilmu yang tidak menerima keraguan, yaitu tersingkapnya sesuatu dengan jelas, sehingga tak ada lagi ruang untuk raguragu, tak mungkin salah ataupun keliru, tak ada di hati tempat untuk itu. ${ }^{29}$ Di sisi lain dia mengatakan bahwa ma'rifah ialah mengetahui rahasia Allah dan peraturan-peraturanNya tentang segala yang ada. ${ }^{30}$

Sarana ma'rifat adalah kalbu, bukan perasaan dan bukan pula akal budi. Kalbu yang dimaksudkan adalah percikan ruhaniyah ketuhanan yang merupakan hakikat realitas manusia. Jadi ma'rifat dapat dicapai dengan kalbu yang bersih. Artinya bahwa hanya kalbu yang bersihlah yang bisa menerima Nur dari Allah untuk mengenal sesuatu dalam arti yang hakiki. Syarat pertama yang harus dilakukan untuk itu adalah mensucikannya dari tingkah laku yang tercela dan dari dosa-dosa, selanjutnya membersihkannya dari yang selain Allah Swt. Kunci kesucian ini adalah dengan melibatkan kalbu secara total untuk berzikir kepada Allah, dan akhir dari semuanya adalah fana' secara total menuju Allah. yang kemudian berdampak pada al-mukasyafah dan al-Musyahadah sehingga mereka dapat melihat (melalui kalbunya) para malaikat dan roh para Nabi. Kemudian keadaan yang seperti ini akan meningkat lagi hingga tak bisa dilukiskan dengan kata-kata. Akhirnya sampailah mereka pada tingkat yang begitu dekat (pada Tuhan) hingga ada yang mengiranya hulul, ittihad ataupun wusul. ${ }^{31}$ Dalam tasawuf, Al-Ghazali merupakan sufi yang memilih tasawuf sunni yang mendasarkan doktrinnya pada Ahl al-Sunnah wa al-Jama'ah. ${ }^{32}$

Abad ke V Hijriah adalah masa dimana tasawuf sunni berada dalam posisi yang menentukan, yang memungkinkannya untuk tersebar luas di kalangan dunia Islam, dan membuat fondasinya begitu dalam terpancang untuk jangka lama pada berbagai lapisan masyarakat Muslim. ${ }^{33}$

\section{Masa Falsafi}

${ }^{28}$ Sayyed Hossein Nasr \& Oliver Leaman, History Of Islamic Philosophy, (London: Routledge, 1996),

${ }^{29}$ Abu Hamid Al-Ghazali, al-Munqiz Min al-Dalal, (Beirut: al-Maktabah al-Syu'batiyah, t.t.), 26

${ }^{30}$ Abu Hamid al-Ghazali, Ihya' Ulum al-Din, Juz IV, (Cairo: Dar al-Sya'b, t.t.), 300

${ }^{31}$ Asmaran As, Pengantar Studi Tasawuf....., 334

${ }^{32}$ Abu al-Wafa al-Ghanimi al-Taftazani, Sufi dari Zaman ke Zaman..., 160

${ }^{33}$ Abu al-Wafa al-Ghanimi al-Taftazani, Sufi dari Zaman ke Zaman..., 141 
Tasawuf falsafi muncul di abad ke VI dan VII Hijriah setelah sebelumnya sempat tenggelam di abad V H dalam bentuknya yang masih semi-falsafi. Tasawuf falsafi disebut juga sebagai tasawuf nazhari yang ajarannya merupakan hasil perpaduan antara visi mistis dan visi rasional pengasasnya. Berbeda dengan tasawuf sunni, tasawuf falsafi menggunakan terminologi filosofis dalam pengungkapannya, yaitu dari berbagai macam ajaran filsafat yang telah mempengaruhi para tokohnya. ${ }^{34}$ Tasawuf falsafi mulai muncul dengan jelas dalam khazanah Islam sejak abad keenam Hijriyah, meskipun para tokohnya baru terkenal seabad kemudian. Sejak abad keenam Hijriyah itulah muncul sekelompok tokoh tasawuf yang memadukan setengah-setengah antara tasawuf dengan filsafat. Menurut at-Taftazani, ciri umum dari tasawuf falsafi adalah ajarannya yang samar-samar dikarenakan banyaknya istilah khusus yang hanya dipahami oleh siapa saja yang memahami ajaran tasawuf jenis ini. ${ }^{35}$

Tasawuf falsafi juga memiliki karakteristik khusus yang kemudian menjadi pembeda dengan tasawuf sunni, yaitu:

1. Tasawuf falsafi banyak mengonsepsikan pemahaman ajarannya dengan menggabungkan antara pemikiran rasional filosofis dan perasaan (dzauq). Meski demikian, tasawuf falsafi juga sering mendasarkan pemikirannya dengan mengambil sumber-sumber naqliyyah, tetapi dengan interpretasi dan ungkapan yang samar-samar serta sulit untuk dipahami orang lain. Kalaupun dapat diinterpretasikan oleh orang lain, interpretasi itupun cenderung kurang tepat dan lebih bersifat subjektif,

2. Seperti halnya tasawuf sunni, tasawuf falsafi juga didasarkan pada latihan-latihan rohaniah (riyadhah), yang dimaksudkan sebagai peningkatan moral dan mencapai kebahagiaan,

3. Tasawuf falsafi memandang iluminasi sebagai metode untuk mengetahui hakikat realitas, yang menurut penganutnya dapat dicapai dengan fana',

4. Para penganut tasawuf falsafi selalu menyamarkan ungkapan-ungkapan tentang hakikat realitas dengan berbagai simbol atau terminologi. ${ }^{36}$

Kebangkitan kembali tasawuf semi-falsafi menjadi tasawuf falsafi ini dibarengi dengan munculnya beberapa thariqah dalam tasawuf. Tasawuf falsafi dikembangkan oleh para sufi yang berlatarbelakang sebagai filosof, di samping sebagai sufi juga. Tasawuf falsafi merupakan tasawuf yang ajaran-ajaran serta konsepsinya disusun begitu rumit hingga

\footnotetext{
${ }^{34} \mathrm{Abu}$ al-Wafa al-Ghanimi at-Taftazani, Sufi dari Zaman ke Zaman..., 187

${ }^{35}$ M. Sholihin dan Rosihon Anwar, Ilmu Tasawuf,(Bandung: Pustaka Setia, 2011), 174

${ }^{36}$ Samsul Munir Amir, Ilmu Tasawuf..., 267
} 
membutuhkan pemahaman yang mendalam dengan menggunakan bahasa-bahasa yang simbolik-filosofis. Oleh karenanya tidak mengherankan jika mayoritas sufi yang memiliki paham tasawuf ini akan mengalami kemabukan spiritual (ekstasi) hingga mengeluarkan statement-statement yang terkesan tidak awam (syathahiyat). ${ }^{37}$

Tokoh utama yang memprakarsai tasawuf falsafi adalah Ibn Arabi dengan Wahdat alWujud, Suhrawardi dengan teori Isyraqiyah, Ibn Sabi'in dengan teori Ittihad, dan Ibn Faridh dengan teori cinta, fana', serta Wahdat al-Syuhud. ${ }^{38}$ Sementara thariqah yang bermunculan di abad ini (terkhusus abad ke VII H) adalah tarekat Qadiriyyah, tarekat Naqshabandiyah, tarekat Maulawiyah, dan beberapa tarekat yang lain. ${ }^{39}$

\section{Ibn Arabi}

Nama lengkapnya adalah Muhammad bin Ali bin Ahmad bin Abdullah ath-Tha'i alHitami. Lahir di Murcia, Andalusia Tenggara, Spanyol pada tahun $560 \mathrm{H}$, dan meninggal di Hijaz tahun 638 H. Ajaran sentral Ibn Arabi adalah tentang Wahdat al-Wujud (kesatuan wujud). Menurutnya, wujud semua yang ada ini hanya satu, dan wujud makhluk pada hakikatnya adalah wujud Khaliq juga. Tidak ada perbedaan dari segi hakikat dari keduanya. Kalaupun ada yang mengira tentang adanya perbedaan di antara keduanya, hal itu dilihat dari sudut pandang pancaindra lahir dan akal yang terbatas kemampuannya dalam menangkap hakikat apa yang ada pada Dzat-Nya dari kesatuan dzatiah yang segala sesuatu terhimpun pada-Nya.

Menurut Ibn Arabi, wujud alam pada hakikatnya adalah wujud Allah dan Allah adalah hakikat alam, tidak ada perbedaan antara wujud yang qadim (Khaliq) dengan wujud yang baru (makhluk). Tiada perbedaan antara abid (penyembah) dengan ma'bud (yang disembah), bahkan keduanya adalah satu. Satu-satunya wujud yang ia maksudkan adalah wujud Tuhan, yaitu wujud yang mutlak, tidak ada wujud selain wujud-Nya. Dengan demikian, kata wujud tidak diberikan kepada selain Tuhan. ${ }^{40}$ Dalam menjelaskan hubungan Tuhan dengan alam, Ibn Arabi menjelaskan bahwa alam adalah bayangan Tuhan atau bayangan wujud yang hakiki dan alam tidak mempunyai wujud yang sesungguhnya. Oleh karenanya, alam merupakan tempat tajali dan mazhar (penampakan) Tuhan. Dalam Fushush al-Hikam, Ibn Arabi menjelaskan melalui syairnya yang berbunyi:

\footnotetext{
${ }^{37}$ M. Solihin, Melacak Pemikiran Tasawuf di Nusantara, (Jakarta: Raja Grafindo Persada, 2005), 10

${ }^{38}$ Amin Syukur, Menggugat Tasawuf....,40

39 Ja'far Shodiq, Pertemuan Tarekat dan NU, (Yogyakarta: Pustaka Pelajar, 2008), 31

${ }^{40}$ M. Sholihin dan Rosihon Anwar, Ilmu Tasawuf..., 180
} 


\section{وما الوجه إلا و احد \#\# غير انه إذا أنت أعددت المر ايا تعددا}

Terjemahnya:

"wajah itu sebenarnya hanya satu, tetapi jika anda perbanyak cermin, maka ia pun menjadi banyak."41

\section{Masa Pemurnian}

Masa keemasan gerakan tasawuf baik secara teoritis maupun praktis terjadi pada tokoh Ibn Arabi, Ibn Faridh, dan Jalaluddin Rumi. Pengaruh dan praktek-praktek tasawuf tersebar luas melalui tarekat-tarekat. Bahkan para sultan dan pangeran tidak segan lagi memberikan perlindungan dan mengikuti ajaran mereka. Meski demikian, lama kelamaan dalam tasawuf mulai muncul penyelewengan-penyelewengan dan skandal yang berakhir pada kehancuran citra baik tasawuf itu sendiri. Ketika itu tasawuf dihinggapi bid'ah, klenik, pengabdian syari'at, hukum-hukum moral dan penghinaan terhadap ilmu pengetahuan. ${ }^{42}$ Dengan adanya fenomena tersebut, menjadikan Ibn Taimiyah dengan lantang menyerang ajaran-ajaran yang dia anggap menyeleweng tersebut. Ibn Taimiyah ingin mengembalikan tasawuf pada sumber ajaran Islam, yakni al-Qur'an dan Hadis.

Hal yang dikritik oleh Ibn Taimiyah adalah ajaran ittihad, hulul, Wahdat al-Wujud, pengkultusan wali yang dianggapnya sebagai bid'ah, khurafat, dan takhayyul. Meskipun demikian, Ibn Taimiyah masih memberikan toleransi terhadap ajaran fana', namun dengan pemaknaan yang berbeda. Dia membagi fana ' menjadi tiga bagian, yakni fana' ibadah (lebur dalam ibadah), fana' syuhud al-Qalb (fana' pandangan batil), dan fana' wujud masiwa Allah (fana' wujud selain Allah).

Menurut Ibn Taimiyah, fana' yang pertama dan kedua itu masih sesuai dengan ajaran Islam, sementara fana' yang ketiga telah terjadi penyelewengan dan pelakunya dihukumi kafir, karena ajaran tersebut beranggapan bahwa wujud Khaliq adalah wujud makhluq. Kemudian secara garis besar, ajaran taswuf Ibn Taimiyah tidak lain ialah melakukan apa yang pernah diajarkan Rasulullah Saw., yaitu menghayati ajaran Islam tanpa mengikuti aliran tarekat tertentu, namun tetap melibatkan diri dalam kegiatan sosial sebagaimana khalayak umum. $^{43}$

\footnotetext{
${ }^{41}$ Ibn Arabi, Fushush al-Hikam wa Ta'liqat 'alaih, Ed. Abu al-A'la Afifi, (Beirut: Dar al-Fikr, t.t), 70

${ }^{42}$ Amin Syukur, Menggugat Tasawuf...,42

${ }^{43}$ Aly Mashar, Tasawuf: Sejarah, Madzhab, dan Inti Ajarannya, Al-A'raf: Jurnal Pemikiran Islam dan
} Filsafat, Vol. XII, No. 1, Juni 2015, 13 


\section{PENUTUP}

Tasawuf merupakan bagian dari syari'at Islam yang ajarannya lebih fokus pada penyucian jiwa guna mencapai kedekatan, kecintaan, dan kesatuan dengan Allah sebagai penciptanya. Secara historis tasawuf dapat dibagi menjadi beberapa masa, yaitu masa pembentukan, masa pengembangan, masa konsolidasi, masa falsafi, dan masa pemurnian. Dari beberapa masa tersebut bisa diketahui adanya dua aliran dalam tasawuf, yakni tasawuf semi-falsafi yang kemudian menjadi tasawuf falsafi dan tasawuf sunni.

Kedua aliran inilah yang kemudian mewarnai dunia tasawuf. Tasawuf sunni dikategorikan sebagai tasawuf sadar, di mana pemahaman kesufiannya dijelaskan secara sederhana, sehingga dapat dimengerti dan dipahami oleh semua kalangan. Ajaran-ajaran dalam tasawuf sunni lebih mengarah pada perilaku yang sesuai dengan al-Qur'an dan Sunnah Nabi Muhammad Saw, sehingga untuk menjadi calon sufi haruslah memahami syari'at dengan sangat baik. Sedangkan tasawuf falsafi lebih mendasarkan ajarannya pada rasio dan perasaan (dzauq), namun bukan berarti meninggalkan syari'at, kedua aliran tasawuf ini (sunni dan falsafi) sama-sama mengutamakan syari'at, hanya saja pemahaman kesufian aliran falsafi agak rumit untuk dipahami oleh manusia pada umumnya, karena ungkapan yang digunakan adalah ungkapan-ungkapan yang samar-samar (syathahiyyat) dan mengandung unsur simbolik, sufi nya pun mengalami ekstasi (kemabukan spiritual). 


\section{DAFTAR PUSTAKA}

Al-Ghazali, Abu Hamid. al-Munqiz Min al-Dalal. Beirut: al-Maktabah al-Syu'batiyah. t.t.

Al-Ghazali, Abu Hamid. Ihya' Ulum al-Din. Juz IV. Cairo: Dar al-Sya'b. t.t.

Al-Hujwiri, Abu al-Hasan Ali ibn Utsman. Kasyf al-Mahjub: The Oldest Persian Treatise On Sufisme. New Delhi: Taj Company. 1999.

Al-Tusiy, Al-Sarraj. al-Luma' fi Tarikh al-Tasawwuf al-Islamiy. Beirut: Dar al-Kutub alIlmiyyah. 2007.

Amir, Samsul Munir Amir. Ilmu Tasawuf. Jakarta: Amzah. 2012.

Anshori, Afif. Tasawuf Filsafat Syaikh Hamzah Fansuri. Jakarta: Gelombang Pasang. 2004.

Arabi, Ibn. Fushush al-Hikam wa Ta'liqat 'alaih. Ed. Abu al-A'la Afifi. Beirut: Dar al-Fikr. t.t

Arberry, A.J. Sufism: An Account of The Mystics of Islam. London: George Allen \& Unwin. 1979.

At-Taftazani, Abu al-Wafa al-Ghanimi. Sufi dari Zaman ke Zaman. terj. Ahmad Rifa'i Ustmani. Bandung: Pustaka. 1985.

Burhani, Ahmad Najib. Manusia Modern Mendamba Allah: Renungan Tasawuf Positif. Jakarta: Mizan. 2002.

Daradjat, Zakiah. Pengantar Ilmu Tasawuf. Sumatera Utara: Institut Agama Islam Negeri. 1982.

Mashar, Aly. Tasawuf: Sejarah, Madzhab, dan Inti Ajarannya. Al-A'raf: Jurnal Pemikiran Islam dan Filsafat. Vol. XII. No. 1. Juni 2015.

Nasution, Harun. Filsafat dan Mistisime dalam Islam. Jakarta: Bulan Bintang. 1973.

Nicholson, R.A. The Mystic of Islam. London: Routledge and Kegan Paul Ltd. 1966.

Nicholson, R.A. Fi al-Tasawwuf al-Islami wa Tarikhihi. Kairo: Dar al-Ta'lif. 1969.

Noer, Kautsar Azhari. Tasawuf Perenial Kearifan Kritis Kaum Sufi. Jakarta: Serambi. 2002.

Sayyed Hossein Nasr \& Oliver Leaman. History Of Islamic Philosophy. London: Routledge. 1996.

Shodiq, Ja'far. Pertemuan Tarekat dan NU. Yogyakarta: Pustaka Pelajar. 2008.

Sholihin, M. Melacak Pemikiran Tasawuf di Nusantara. Jakarta: Raja Grafindo Persada. 2005.

Sholihin, M. dan Rosihon Anwar. Ilmu Tasawuf. Bandung: Pustaka Setia. 2011.

Spencer J. Trimingham. The Sufi Orders in Islam. London: Oxford University Press. 1971.

Syukur, M. Amin. Menggugat Tasawuf: Sufisme dan Tanggung Jawab Sosial Abad 21. Yogyakarta: Pustaka Pelajar. 2002. 